\title{
Prenatal and postnatal features of mesenchymal hamartoma of the chest wall: case report and literature review
}

\author{
Yelda Jozaghi · Sherif Emil · Pedro Albuquerque • \\ Stephanie Klam • Miriam Blumenkrantz
}

Accepted: 29 January 2013/Published online: 15 March 2013

(C) Springer-Verlag Berlin Heidelberg 2013

\begin{abstract}
Mesenchymal hamartoma of the chest wall is a rare, benign chondro-osseous tumor of the bone. Although it most commonly presents at birth or soon after, prenatal detection is rare. We report a case of prenatally detected mesenchymal hamartoma, and provide the rationale, details, and outcomes of our management. The literature is reviewed, with particular attention to prenatal detection and postnatal management options.
\end{abstract}

\section{Introduction}

Mesenchymal hamartoma of the chest wall (MHCW) is a rare, benign chondro-osseous tumor of the bone that manifests at birth or shortly thereafter. It represents 1 in 3,000 primary bone tumors, and has an incidence of less than one in a million within the general population [1]. The tumor typically presents as a chest wall mass in a newborn

Y. Jozaghi · P. Albuquerque

Division of Pediatric Radiology, McGill University

Faculty of Medicine, Montreal, QC, Canada

S. Emil $(\bowtie)$

Division of Pediatric General and Thoracic Surgery, Montreal Children's Hospital, McGill University Health Centre, 2300 Tupper Street, Room C-818, Montreal, QC H3H 1P3, Canada

e-mail: Sherif.emil@McGill.ca

S. Klam

Department of Obstetrics and Gynecology, Jewish General Hospital, McGill University

Faculty of Medicine, Montreal, QC, Canada

M. Blumenkrantz

Division of Pediatric Pathology, McGill University

Faculty of Medicine, Montreal, QC, Canada or infant, sometimes accompanied by respiratory distress secondary to lung compression. We present a case of prenatally detected and postnatally diagnosed bilateral MHCW in a girl. The rationale of the management plan and 2-year follow-up is provided.

\section{Case report}

A 27-year-old primigravid black woman, with no significant past medical history, presented for pediatric surgical fetal consultation secondary to a right thoracic mass detected on ultrasound at 28 weeks of gestation. The mass consisted of solid and cystic components and measured $2.3 \mathrm{~cm}$ in greatest dimension. The remainder of the fetal survey was normal, and no polyhydramnios or pleural effusions were noted. A previous ultrasound, performed at 21 weeks, had shown a female fetus without any obvious congenital anomalies. A presumptive diagnosis of congenital cystic adenomatoid malformation was made, and the patient was followed with biweekly ultrasounds.

At 32 weeks gestation, a new cystic-solid left-sided lung mass measuring $3.8 \times 3.5 \times 3.7 \mathrm{~cm}$ was apparent, in addition to the right-sided lesion which now appeared to have a calcified rim (Fig. 1). Fluid-fluid levels could be seen within the cysts of the left-sided mass, while the right sided mass appeared more hyperechoic, suggesting an internal hemorrhage. Weekly ultrasounds revealed differing growth patterns of the bilateral thoracic lesions. The initial right-sided lesion halted in its progression, whereas the left-sided lesion continued to increase in size. The fetus continued to progress well.

The mother underwent induced vaginal delivery at 39 weeks gestation. An asymptomatic baby girl was born and immediately transferred to our neonatal intensive care unit. Physical examination showed an eccentric left-sided 
chest wall deformity with no palpable external masses. A chest X-ray showed bilateral rib abnormalities, in addition to two masses within the chest: a small right sided mass and a much larger left-sided one displacing the heart (Fig. 2). A CT scan of the chest, performed on the second day of life, showed one lesion arising from the right, and multiple lesions arising from the left chest wall (Fig. 3). They all showed peripheral, irregular, bony rims with remodeling of the ribs. A diagnosis of bilateral mesenchymal hamartoma of the chest wall was suspected. A multidisciplinary discussion with radiology, pathology, and oncology resulted in a decision to obtain histologic diagnosis.

The parents were Jehova's Witnesses, and strongly requested the avoidance of blood transfusion. The safest course was felt to be an excisional biopsy of the right-sided lesion rather than an incisional biopsy of the large leftsided one. Since the right-sided lesion could not be palpated, a thoracoscopic-assisted excisional biopsy of the

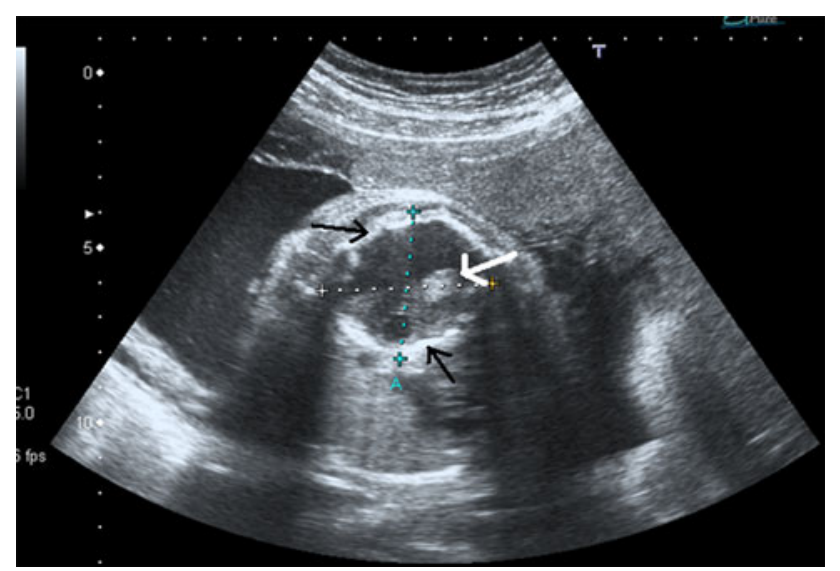

Fig. 1 Ultrasound at 32 weeks gestation showing a mass consisting of solid and cystic components, with calcified borders (black arrows) and a hyperechoic focus (white arrow), suggesting internal hemorrhage

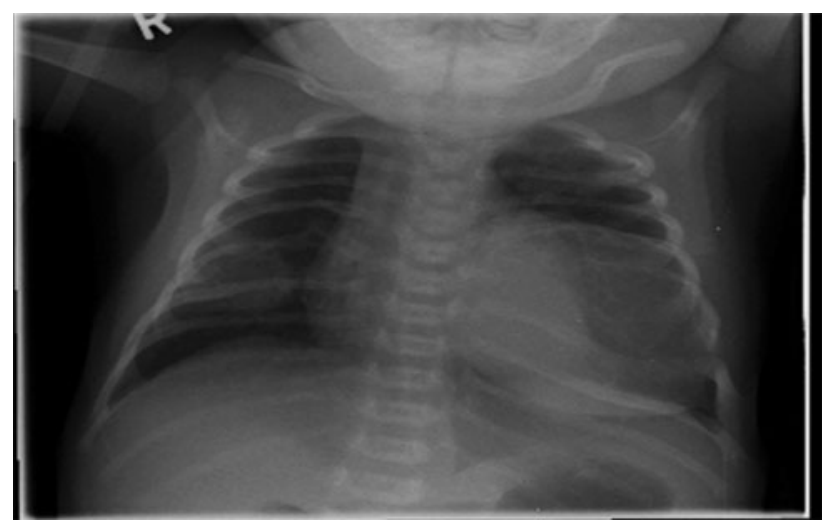

Fig. 2 Chest X-ray at birth showing bilateral rib abnormalities, in addition to a small right-sided mass and a much larger left sided one displacing the heart lesion was performed on the fourth day of life. Tracheal intubation and insufflation of carbon dioxide into the right thorax was used to obtain partial lung collapse. Using two 3-mm trocars and one 5-mm trocar, the mass was localized and partially mobilized by incising the covering parietal pleura (Fig. 4). A limited chest wall incision was then used to resect the lesion, which was based on a portion of the 6th and 7th ribs; The defect in the chest wall was reconstructed with a very redundant Goretex patch to allow for growth. The patient was discharged on the third post-operative day.

Pathological examination showed a well-encapsulated lesion with both cellular hemorrhagic components and solid areas composed of spindle to stellate cells within a myxoid stroma, with minimal to mild atypia (Fig. 5). These features were typical of MHCW of infancy.

The patient is undergoing regular follow-up at a multidisciplinary chest wall anomalies clinic. At 2 years of age, she is developing normally without chest asymmetry or scoliosis, and remains asymptomatic from a respiratory point of view. Follow-up chest X-rays have shown significant regression of the large left-sided lesion (Fig. 6).

\section{Discussion}

Mesenchymal hamartoma of the chest wall (MHCW) is a benign chondro-osseous lesion involving one or more ribs that manifests at birth or shortly afterward [1-3]. It was first described in 1948 and named mesenchymomas as a way to describe the histological presence of at least two mesenchymal tissues that are not typically found together $[2,4-6]$. The term hamartoma, disorganized tissue indigenous to the location, was suggested in 1979 by McLeod and Dahlin [7]. In order to demonstrate the histological characteristics of a self-limiting non-neoplastic lesion. In 1986, Odell and Benjamin [8] reconciled both notions by referring to the entity as mesenchymal hamartoma. The lesion has also been referred to in the literature as osteochondroma, osteochondrosarcoma, benign chondroblastoma, and chondromatous hamartoma [2]. In addition to chondroid tissue, the tumor is composed of large endothelium-lined blood spaces and areas of spindle cell proliferation [7].

Although radiologic features are not considered pathognomonic for MHCW, characteristic features have been noted [6, 9-12]. A large, heterogenous, expansile rib lesion appearing as an extrapleural soft tissue mass with areas of calcification and fluid-filled cysts, commonly accompanied with some parenchymal compression and mediastinal shift, is the typical appearance of MHCW on CT scan [11, 13]. Two specific findings may allow differentiation of MHCW from malignant tumors [14]. First, chest X-ray will often show destruction of the ribs of origin, accompanied by 
Fig. 3 Two coronal views of CT scan of the chest showing one lesion arising from the right, and multiple lesions arising from the left chest wall. The large left-sided mass contains a hemorrhagic component
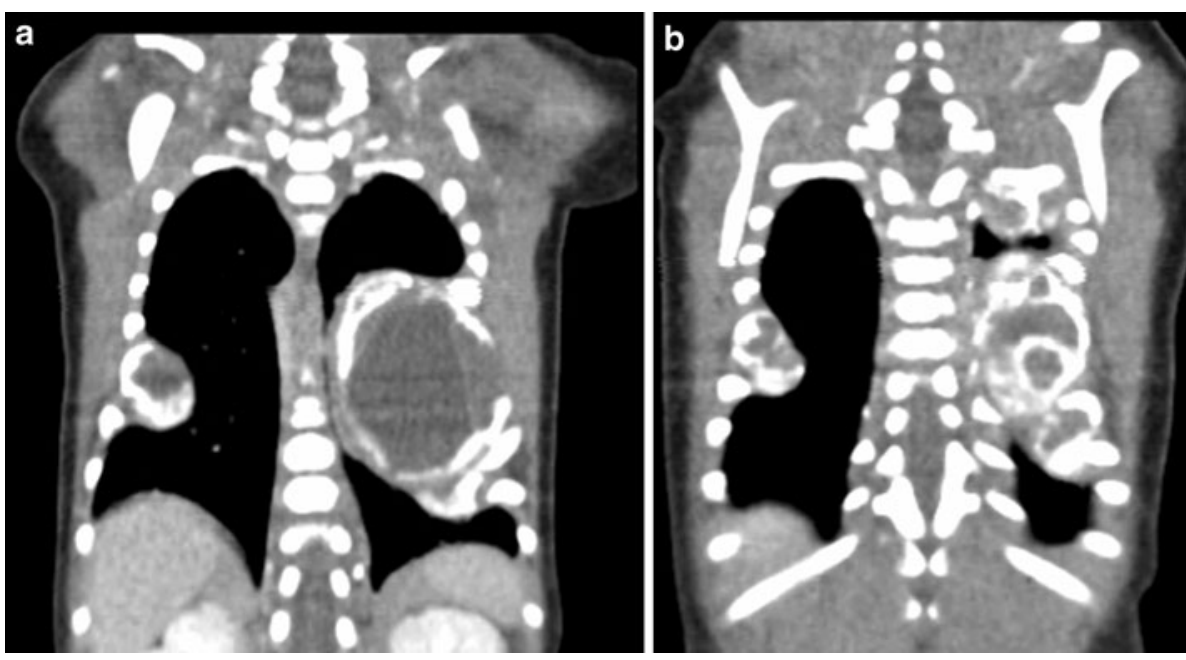

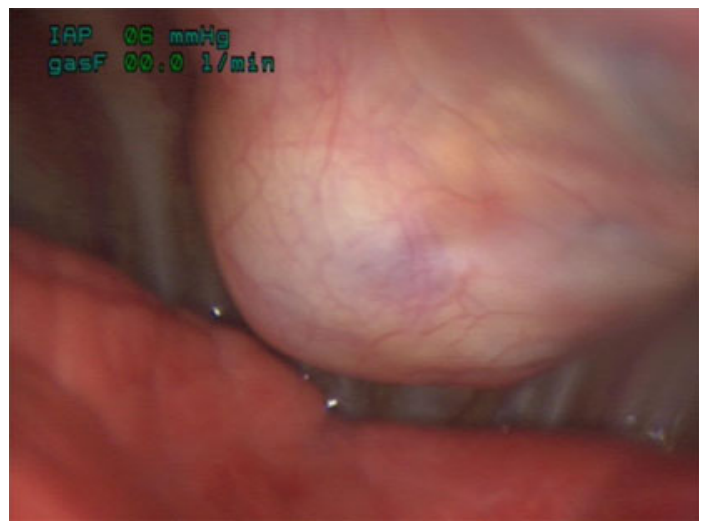

Fig. 4 View of the right-sided mass on thoracoscopy. Intact parietal pleura and normal lung can be seen

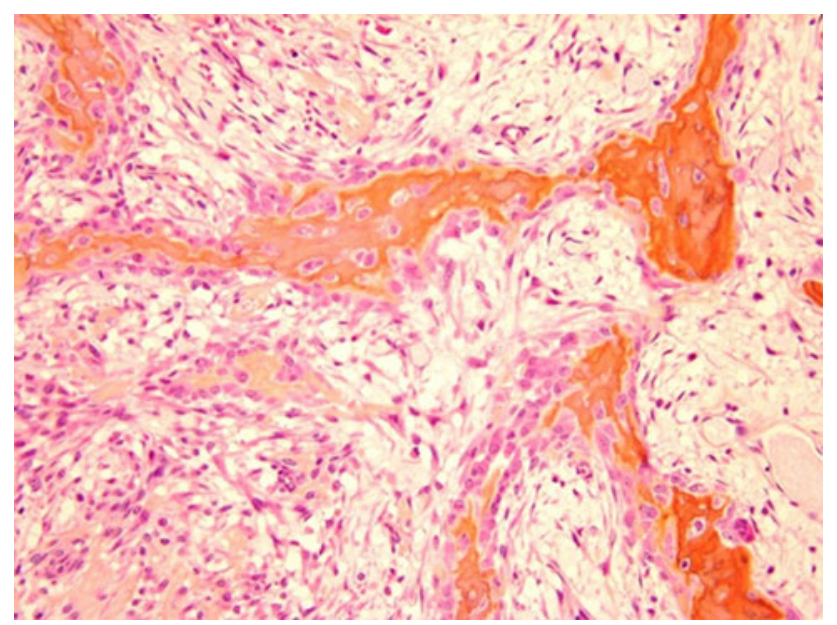

Fig. 5 Histology of the specimen showing typical features of MHCW (see text)

deformation of the peripheral ribs. Second, MHCW will classically present with a lesion that arises centrally from one or multiple ribs away from the costochondral and

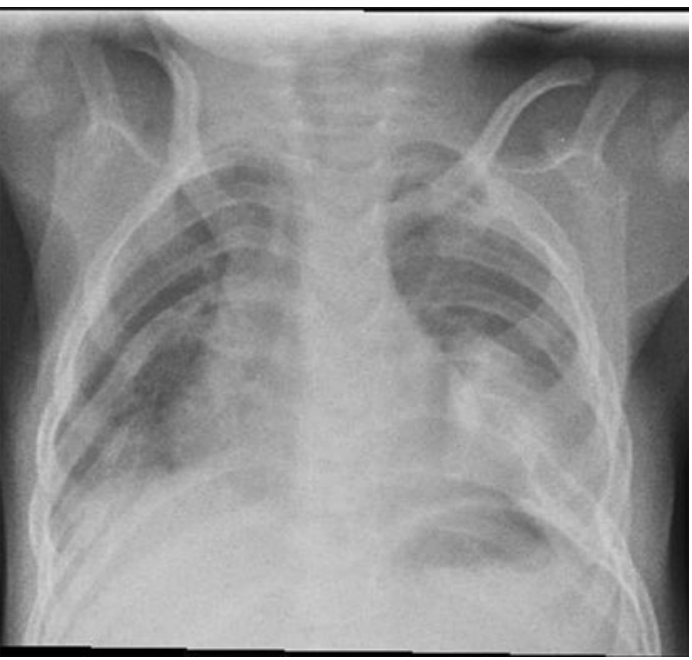

Fig. 6 Chest X-ray at 18 months of age showing regression of the left thoracic mass in proportion to the thoracic cavity

costovertebral junctions. However, imaging has not been considered diagnostic of $\mathrm{MHCW}$, a lesion that still mimics chest wall malignancy due to its destructive nature [15]. All previous reports obtained tissue for diagnosis. This led us to perform an excisional biopsy of the smaller, more conveniently located lesion.

Hypoplasia of the lung may develop if the tumor starts early in utero. [2]. Variable growth patterns are observed, with generally rapid initial growth followed by slower growth, arrest, or regression [2]. Clinically, neonates present with variable chest wall deformities that may or may not be associated with respiratory or cardiac compromise [1]. These lesions are rarely reported after infancy. Two cases have been reported in teenage girls [14, 16], and one in a middle-aged man. [17] A case has also been reported in a child with Beckwith-Wiedemann syndrome. [13] No other syndromal associations have been found, even when the lesions have been multifocal or bilateral. 
The lesion in our patient was detected, but not diagnosed, on prenatal ultrasound. We found only ten cases of prenatally detected $\mathrm{MHCW}$ prior to this report (Table 1) [1, 6, 18-25]. A prenatal diagnosis was only made twice [21, 25]. In 1996, Masuzaki et al. [21] made the diagnosis using a combination of prenatal ultrasound and CT scan, an approach that would not be used in the current era. More recently, Chu et al. [25] were able to make a prenatal diagnosis using MRI. In both cases, bony involvement and calcification aided in differentiating of MHCW from congenital cystic adenomatoid malformation or sequestration. These two diagnoses were originally considered, but subsequently dismissed in our case. The definitive diagnosis was not made simply due to the rarity and lack of familiarity with this lesion.

Most of these pregnancies were complicated, with polyhydramnios in $50 \%$, pleural effusions in $50 \%$, and pericardial effusions in one case. Eight of the ten births were complicated by fetal distress, preterm labor, or respiratory distress. Our case is also unique in that the pregnancy and delivery were uncomplicated, and the baby was asymptomatic despite very large lesions.

Resection of the lesion may be indicated in a symptomatic patient. In addition, as mentioned earlier, biopsy has generally been required to establish a final diagnosis. These are highly vascular lesions. Biopsy of a hamartoma can be complicated by severe bleeding due to disruption of the endothelium-lined vascular spaces [26]. In our case, the situation was further complicated by the very strong desire of the parents to avoid blood transfusions due to their religious beliefs. A thoracoscopic-guided excisional biopsy of the small right sided lesion optimized safety by avoiding entry into the lesion. We believe this is the first report of the use of thoracoscopy in managing this lesion.

Scoliosis is noted as a major long-term morbidity in patients with MHCW. This is probably secondary to

Table 1

\begin{tabular}{|c|c|c|c|c|c|c|c|c|}
\hline Report & $\begin{array}{l}\text { Gestational } \\
\text { age at } \\
\text { detection } \\
\text { (weeks) }\end{array}$ & $\begin{array}{l}\text { Indication for } \\
\text { ultrasound }\end{array}$ & Sex & $\begin{array}{l}\text { No. of } \\
\text { lesions }\end{array}$ & Site & $\begin{array}{l}\text { Prenatal } \\
\text { complications }\end{array}$ & Peri-natal complications & Treatment \\
\hline $\begin{array}{l}\text { Brar et al. } \\
\text { [18] }\end{array}$ & $\begin{array}{l}\text { Estimated } \\
33-35\end{array}$ & $\begin{array}{l}\text { Large for } \\
\text { dates }\end{array}$ & M & 1 & Right & $\begin{array}{l}\text { Polyhydramnios; } \\
\text { pleural effusion }\end{array}$ & $\begin{array}{l}\text { C-section at } 37 \text { weeks due to } \\
\text { fetal distress; respiratory } \\
\text { distress }\end{array}$ & $\begin{array}{l}\text { Debulking at } \\
1 \text { month }\end{array}$ \\
\hline $\begin{array}{l}\text { D'Ercole } \\
\text { et al. [19] }\end{array}$ & 29 & NS & M & 1 & Left & Pleural effusion & $\begin{array}{l}\text { C-section due to abnormal } \\
\text { fetal HR at labor onset }\end{array}$ & $\begin{array}{l}\text { Resection at } \\
12 \text { days }\end{array}$ \\
\hline $\begin{array}{l}\text { Jung et al. } \\
\text { [20] }\end{array}$ & 35 & $\begin{array}{l}\text { Large for } \\
\text { dates }\end{array}$ & M & 1 & Right & Polyhydramnios & $\begin{array}{l}\text { C-section at } 37 \text { weeks due to } \\
\text { early onset labor and fetal } \\
\text { distress; respiratory failure }\end{array}$ & $\begin{array}{l}\text { Debulking at } 1 \\
\text { and } 9 \text { months }\end{array}$ \\
\hline $\begin{array}{l}\text { Masuzaki } \\
\text { et al. [21] }\end{array}$ & 36 & $\begin{array}{l}\text { Fetal pleural } \\
\text { effusion }\end{array}$ & M & 1 & Right & $\begin{array}{l}\text { Polyhydramnios; } \\
\text { pleural effusion }\end{array}$ & $\begin{array}{l}\text { Respiratory failure; recurrent } \\
\text { pleural effusion }\end{array}$ & $\begin{array}{l}\text { Resection at } \\
13 \text { days }\end{array}$ \\
\hline $\begin{array}{l}\text { Rose et al. } \\
\text { [22] }\end{array}$ & $\begin{array}{l}\text { Second } \\
\text { trimester }\end{array}$ & $\begin{array}{l}\text { Possible } \\
\text { gastroschisis }\end{array}$ & $\mathrm{F}$ & 1 & NS & None & Preterm labor 36 weeks & $\begin{array}{l}\text { Resection at } \\
10 \mathrm{~h}\end{array}$ \\
\hline $\begin{array}{l}\text { Lisle et al. } \\
{[6]}\end{array}$ & NS & NS & $\mathrm{F}$ & Multiple & Bilateral & Polyhydramnios & $\begin{array}{l}\text { Cyanosis; airway compromise } \\
\text { requiring tracheostomy }\end{array}$ & Observation \\
\hline $\begin{array}{l}\text { Shimotake } \\
\text { et al. [23] }\end{array}$ & 28 & NS & $\mathrm{F}$ & 1 & Left & $\begin{array}{l}\text { Polyhydramnios; } \\
\text { no left lung } \\
\text { identified }\end{array}$ & $\begin{array}{l}\text { Respiratory distress; preterm } \\
\text { labor } 36 \text { weeks; persistent } \\
\text { pulmonary hypertension }\end{array}$ & Observation \\
\hline $\begin{array}{l}\text { Odaka } \\
\text { et al. [24] }\end{array}$ & 29 & NS & M & 1 & Right & Pleural effusion & $\begin{array}{l}\text { C-section at } 33 \text { weeks due to } \\
\text { fetal distress; respiratory } \\
\text { distress at birth }\end{array}$ & $\begin{array}{l}\text { Resection at } \\
8 \text { days }\end{array}$ \\
\hline $\begin{array}{l}\text { Braatz } \\
\text { et al. [1] }\end{array}$ & 24 & Routine & M & Multiple & Right & None & None & Observation \\
\hline $\begin{array}{l}\text { Chu et al. } \\
\text { [25] }\end{array}$ & 32 & Routine & $\mathrm{F}$ & Multiple & Bilateral & Pleural effusion & None & $\begin{array}{l}\text { Resection of } \\
\text { largest lesion } \\
\text { at } 6 \text { weeks }\end{array}$ \\
\hline $\begin{array}{r}\text { Present } \\
\text { report }\end{array}$ & 27 & Routine & $\mathrm{F}$ & Multiple & Bilateral & $\begin{array}{l}\text { Small pericardial } \\
\text { effusion }\end{array}$ & None & $\begin{array}{l}\text { Excisional } \\
\text { biopsy of } \\
\text { smaller lesion } \\
\text { at } 3 \text { days }\end{array}$ \\
\hline
\end{tabular}

$N S$ not specified, $H R$ heart rate, $M$ male, $F$ female 
resection of a large part of the thoracic cage, as well as to the skeletal deformity caused by the tumor itself [9]. Avoiding resection of the posterior aspect of the rib cage, if possible, may minimize the degree of scoliosis [27]. The literature reports three deaths secondary to $\mathrm{MHCW}[2,6$, 7]. Two of these occurred shortly after birth due to respiratory compromise secondary to lesions that occupied almost the entire hemithorax [2, 7]. A third occurred secondary to complications of chemotherapy following a misdiagnosis of embryonal sarcoma [6]. A single case of malignant transformation was suspected, but the diagnosis subsequently changed to fibrous hamartoma of infancy, an entity separate from MHCW [6, 28]. Multiple cases of spontaneous regression have also been reported, strongly arguing for a conservative approach in asymptomatic patients [29-32]. Our patient continued to be asymptomatic at 2 years of age, and has not yet exhibited any evidence of scoliosis or chest wall anomaly. The lesion appears to be regressing in proportion to the hemithorax on progressive chest X-rays.

This case, along with the literature review, allows us to present a management algorithm for these lesions. MHCW should be added to the list of thoracic lesions amenable to prenatal diagnosis. The diagnosis should be suspected if findings, including calcifications, atypical of the more common congenital lung and mediastinal lesions, are seen on ultrasound. Bilateral lesions should increase the suspicion [33, 34]. A prenatal MRI may help confirm the diagnosis. All patients should be imaged by CT or MRI after birth. There is now sufficient experience in the literature to allow diagnosis based solely on cross-sectional imaging. Observation alone is enough for asymptomatic lesions. Resection with chest wall reconstruction is indicated for symptomatic lesions.

\section{References}

1. Braatz B, Evans R, Kelman A et al (2010) Perinatal evolution of mesenchymal hamartoma of the chest wall. J Pediatr Surg 45:37-40

2. Cohen MC, Drut R, Garcia C et al (1992) Mesenchymal hamartoma of the chest wall: a cooperative study with review of the literature. Pediatr Pathol 12:525-534

3. Vlychou M, Athanasou NA (2008) Radiological and pathological diagnosis of paediatric bone tumours and tumour-like lesions. Pathol 40:196-216

4. Ozolek JA (2009) Selective pathologies of the head and neck in children: a developmental perspective. Adv Anat Pathol $16: 332-358$

5. Psaila J, Carachi R, Raine PAM et al (1996) Thoracic mesenchymoma of infancy. J Pediatr Surg 31:726-728

6. Lisle DA, Ault DJ, Earwaker JW (2003) Mesenchymal hamartoma of the chest wall in infants: report of three cases and literature review. Australas Radiol 47:78-82
7. McLeod RA, Dahlin DC (1979) Hamartoma (mesenchymoma) of the chest wall in infancy. Radiology 131:657-661

8. Odell JM, Benjamin DR (1986) Mesenchymal hamartoma of chest wall in infancy: natural history of two cases. Pediatr Pathol 5:135-146

9. Kerrey B, Reed J (2007) A neonate with respiratory distress and a chest wall deformity. Pediatr Emerg Care 23:565-569

10. Brand MT, Hatch EI, Schaller RT (1986) Surgical management of the infant with mesenchymal hamartoma of the chest wall. J Pediatr Surg 21:556-558

11. Nicholson SA, Hill DA, Foster KW et al (2000) Fine-needle aspiration cytology of mesenchymal hamartoma of the chest wall. Diagn Cytopathol 22:33-38

12. Oakley RH, Carty H, Cudmore RE (1985) Multiple benign mesenchymomata of the chest wall. Pediatr Radiol 15:58-60

13. Jonas RE, Kimonis VE (2001) Chest wall hamartoma with Wiedemann-Beckwith syndrome: clinical report and brief review of chromosome 11p15.5-related tumors. Am J Med Genet 101:221-225

14. Groom KR, Murphey MD, Howard LM et al (2002) Mesenchymal hamartoma of the chest wall: radiologic manifestations with emphasis on cross-sectional imaging and histopathologic comparison. Radiol 222:205-211

15. Yeshvanth SK, Shivamurthy V, Patil C et al (2011) Mesenchymal hamartoma of the chest wall - mimicker of malignancy. J Cancer Res Therapeut 7:496-498

16. Conlan AA, Hurwitz SS, Griztman MCD (1982) Giant chondromatous hamartoma of the first rib. A case report. SAMJ 62:703-704

17. Altaner S, Yoruk Y, Bilgi S et al (2006) Multifocal mesenchymal hamartoma of the chest wall. Respirol 11:334-338

18. Brar MK, Cubberley DA, Baty BJ et al (1988) Chest wall hamartoma in a fetus. J Ultrasound Med 7:217-220

19. D'Ercole C, Boubli L, Potier A et al (1994) Fetal chest wall hamartoma: a case report. Fet Diagn Ther 9:261-263

20. Jung AL, Johnson DG, Condon VR et al (1994) Congenital chest wall mesenchymal hamartoma. J Perinatol 14:487-491

21. Masuzaki H, Masuzaki M, Ishimaru T et al (1996) Chest wall hamartoma diagnosed prenatally using ultrasonography and computed tomography. J Clin Ultrasound 24:83-85

22. Rose NC, Coleman BG, Wallace D et al (1996) Prenatal diagnosis of a chest wall hamartoma and sternal cleft. Ultrasound Obstet Gynecol 7:453-455

23. Shimotake T, Fumino S, Aoi S et al (2005) Respiratory insufficiency in a newborn with mesenchymal hamartoma of the chest wall occupying the thoracic cavity. J Pediatr Surg 40:13-16

24. Odaka A, Takahashi S, Tanimizu $\mathrm{T}$ et al (2005) Chest wall mesenchymal hamartoma associated with a massive fetal pleural effusion: a case report. J Pediatr Surg 40:5-7

25. Chu L, Seed M, Howse E et al (2011) Mesenchymal hamartoma: prenatal diagnosis by MRI. Pediatr Radiol 41:781-784

26. Sodhi KS, Aiyappan SK, Menon P et al (2009) Unilateral multifocal mesenchymal hamartoma of the chest wall: a case report and review of literature. J Pediatr Surg 44:464-467

27. DeRosa GP (1985) Progressive scoliosis following chest wall resection in children. Spine 10:618-622

28. Dounies R, Chwals WJ, Lally KP et al (1994) Hamartomas of the chest wall in infants. Ann Thorac Surg 57:868-875

29. Ayala AG, Ro JY, Bolio-Solis A et al (1993) Mesenchymal hamartoma of the chest wall in infants and children: a clinicopathological study of five patients. Skeletal Radiol 22:569-576

30. Blumenthal BI, Capitanio MA, Queloz JM et al (1972) Intrathoracic mesenchymoma: observations in two infants. Radiology 104:107-109

31. Cameron D, Ong TH, Borzi P (2001) Conservative management of mesenchymal hamartomas of the chest wall. J Pediatr Surg 36:1346-1349 
32. Freeburn AM, McAloon J (2001) Infantile chest hamartomacase outcome aged 11. Arch Dis Child 85:244-245

33. Tsuji Y, Maeda K, Tazuke Y et al (2012) Mesenchymal hamartoma of the bilateral chest wall in neonates. Pediatr Surg Int 28:939-942
34. Li R, Kelly D, Siegal GP (2012) Bilateral mesenchymal hamartoma of the chest wall in an infant boy. Fet Pediatr Pathol $31: 415-422$ 